\title{
Irradiation Assisted Synthesis and Antifungal Activities of Some Mannich Bases*
}

\author{
Shakir M. Saied Asma A. Basher \\ Department of Pharmacy \\ Institute of Technical Mosul
}

Moayed S. AL-Gwady

Department of Chemistry

College of Science

Mosul University

(Received 23/6/2008; Accepted 24/11/2008)

\section{ABSTRACT}

To eliminate the use of solvent during the course of reaction and to decrease the reaction time in addition to enhanced the yield in synthesis of some Mannich bases 5((5-(Aryloxymethyl)-1,3,4-thiadiazol-2-ylamino)(phenyl)methyl)pyrimidine-2,4,6

$(1 \mathrm{H}, 3 \mathrm{H}, 5 \mathrm{H})$-trione $(2 \mathrm{a}-\mathrm{h})$, the reaction was carried out under microwave irradiation of equimolecular mixture of 2-amino-5-aryloxymethyl - 1,3,4 -thiadiazoles (1a-h), benzaldehyde and barbituric acid, using magnesium sulfate as absorption support.

In conventional method the attempts to react amine(1a)with aldehyde to form Schiff base and the reaction of this base with barbituric acid did not succeed.

The structures of these compounds were confirmed by IR Spectrophotometer. All these bases were screened for their antifungal activity against Aspergillus flavus and found to possess weak activity.

Key Words: Mannich base; Microwave synthesis

\section{تحضير بهض قواعدمانخ بطساعة التشعيع بالميكروف وقيلس فعاليتها كمضلة}

\section{الفلربك}

\section{الملغص}

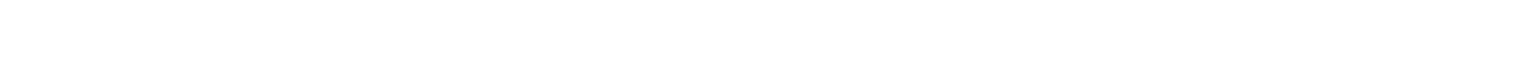
المطناع بعض قواعد مانخ 5(5 -(اريل اوكسى مثل) -4،1، -ثايادايازول -2 -اليل) (فنل مثي لـ لميذ -و)

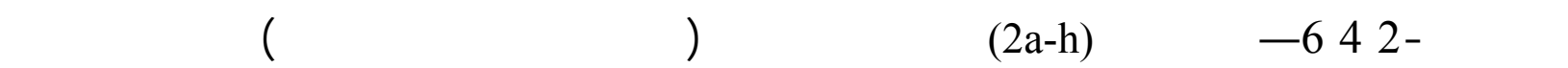

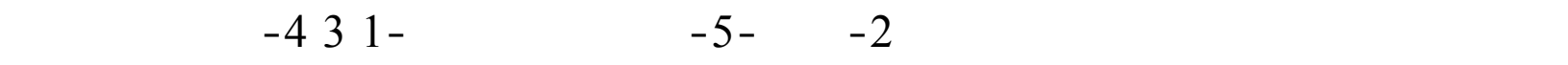

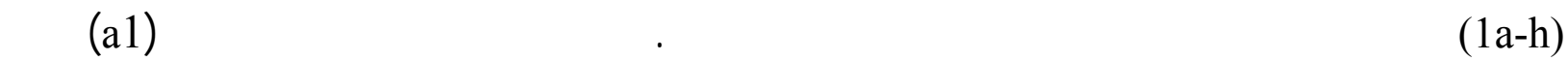
الاليهايد لتحضير قاعةشف ومن م مفاعلتها مع حلمض الباربتيوريك لتحضير قاعة مانخ بالطريق ة

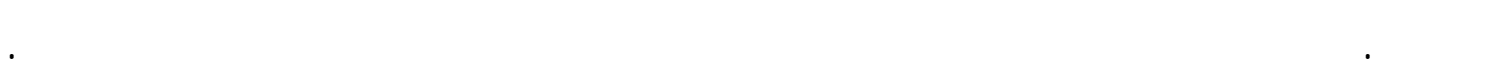

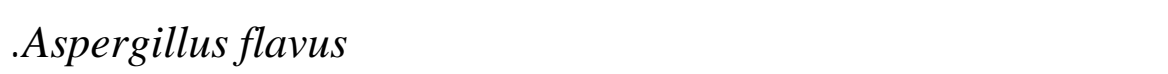

*م إقلاه بالمؤتمر العلهي الأول للكيمياء المنعقد بتاريخ 22-23 نيسان 2008 فـ قم الكيمياء /كلية العلوم/جلمعة الموصل 


\section{INTRODUCTION}

At the beginning of this century, List and Barbas showed that the direct asymmetric Mannich reactions of a broad range of ketones and aldehydes were catalyzed by proline, $\beta$-Amino ketones and aldehydes can be synthesized stereoselectively in good yields (Barbas et al., 2003; Bahmanyar and Houk, 2003).

In the same way Kidwai et al described the use of montmorillonite clay under microwaves to synthesis novel Mannich bases of thiobarbiturates and barbiturates (Kidwai et al., 2005).

As part of continuous program directed toward the studies with polyfunctionally substituted heterocyclic's (Shandala et al., 1998, 2001 and 2002; Ayoub et al., 2001; Basher,2005;Al-Gwady, 2007; Saied, 2007), it was became of interest to investigate preparative routs to synthesis of these Mannich bases which contain more than one center of anticipated antifungal activity such as aryloxy heterocyclic ether linkage (Saied, 1983), pyrimidine moiety (Kidwai et al., 2005) and 1, 3, 4-Thiadiazole ring. Several compounds containing one or both of the first two radicals were proved to show promising growth inhibitory action on different fungus especially Aspergillus flavus (Kidwai et al., 2005). The insertion of 1,3,4-thiadiazole ring was based on the reported fungicidal activity of some compounds containing this ring (Saied, 1983).

\section{EXPERIMENTAL}

All melting points were determined on a Gallen Kamp and Electro thermal 1A9300 Digital-Series (1998) apparatus and were uncorrected. The IR-spectra $\left(\mathrm{vmax} \mathrm{cm}^{-1}\right)$ were recorded on Perkin-Elmer 590B Spectrophotometer. UV-On Shimadzu UV-160 spectrophotometer using EtOH as solvent.

\section{2-Amino-5-aryloxymethyl - 1,3,4 - thiadiazoles (1a-h):}

All these amines were synthesized according to published procedures and had the same physical properties (Saied, 1983):

\section{General Procedure for the Synthesis of 5-((5-(Aryloxymethyl)-1,3,4-thiadiazol-} 2-ylamino) (phenylmethyl) pyrimidine-2,4,6 (1H,3H,5H)-trione (2a-h)

(Kidwai et al., 2005):

Equimolar mixture of $1 \mathrm{a}-\mathrm{h}(0.01 \mathrm{~mol})$, benzaldehydes $(1.06 \mathrm{gm}, 0.01 \mathrm{~mol})$ and barbituric acid (1.28gm, 0.01 mole) were mixed with a spatula for few minutes. The reaction mixture was placed in an open conical flask in a domestic microwave oven (containing crucible of $2 \mathrm{gm}$ magnesium sulfate) and irradiated for $2 \mathrm{~min}$. (the reaction was TLC monitored to indicate the disappearance of the starting material), on completion the mixture was cooled at room temperature and the product was extracted using ethanol.

Evaporation of the solvent under reduced pressure yielded the corresponding title compounds $2 \mathrm{a}-\mathrm{h}$, which were recrystallized from methanol. \%Yields, melting points, in addition to IR were listed in Table (1).

\section{Attempted to synthesis of (2a) by conventional method: (Ralhan et al., 1960)}

An equimolar amount of (1a) and benzaldehyde $(0.01$ mole) were put in a roundbottomed flask. To this, glacial acetic acid in ethanol was added and the reaction mixture was refluxed for 10-12hours with stirrer equipped with condenser. No reaction occurred 
as checked with TLC, and the precipitate has the same melting point of starting material (1a).<smiles>O=C1NC(=O)C(C(Nc2nnc(CO[Ga])s2)c2ccccc2)C(=O)N1</smiles>

Table 1: \%Yields, melting points and IR of compounds (2a-h)

\begin{tabular}{|c|c|c|c|c|c|c|c|}
\hline \multirow[b]{2}{*}{$\begin{array}{c}\text { Compd. } \\
\text { No. } 2\end{array}$} & \multirow[b]{2}{*}{$\mathrm{Ar}$} & \multirow[b]{2}{*}{$\begin{array}{c}\text { Yield } \\
\%\end{array}$} & \multirow[b]{2}{*}{$\underset{{ }^{\circ} \mathrm{Cp}}{\mathrm{Mp}}$} & \multicolumn{4}{|c|}{ IR, KBr ,Cm -1 } \\
\hline & & & & $\begin{array}{c}\mathrm{C}=\mathrm{O} \\
\text { Stretching }\end{array}$ & $\begin{array}{c}\mathrm{N}-\mathrm{H} \\
\text { Stretching }\end{array}$ & $\begin{array}{l}\text { C-O-C } \\
\text { Sym./ } \\
\text { asym. }\end{array}$ & $\begin{array}{l}\mathrm{C}=\mathrm{N} \\
\text { Cyclic }\end{array}$ \\
\hline $\mathrm{a}$ & $\mathrm{C}_{6} \mathrm{H}_{5^{-}}$ & 60 & $390-91$ & 1650 & 3340 & 1190 & 1690 \\
\hline $\mathrm{b}$ & 4- $\mathrm{ClC}_{6} \mathrm{H}_{4-}$ & 55 & $290-93$ & 1650 & 3320 & 1185 & 1680 \\
\hline $\mathrm{c}$ & $2,4-\mathrm{Cl}_{2} \mathrm{C}_{6} \mathrm{H}_{3-}$ & 35 & $290-91$ & 1640 & 3390 & 1210 & 1695 \\
\hline $\mathrm{d}$ & $2,4-\mathrm{Br}_{2} \mathrm{C}_{6} \mathrm{H}_{3}-$ & 65 & $310-11$ & 1650 & 3320 & 1200 & 1685 \\
\hline $\mathrm{e}$ & $4-\mathrm{FC}_{6} \mathrm{H}_{4-}$ & 60 & $331-2$ & 1660 & 3320 & 1220 & 1680 \\
\hline $\mathrm{f}$ & $4-\mathrm{NO}_{2}-\mathrm{C}_{6} \mathrm{H}_{4-}$ & 36 & $319-20$ & 1640 & 3340 & 1195 & 1687 \\
\hline $\mathrm{g}$ & $2-\mathrm{NO}_{2}-\mathrm{C}_{6} \mathrm{H}_{4-}$ & 30 & $310-11$ & 1640 & 3335 & 1180 & 1683 \\
\hline $\mathrm{h}$ & $4-\mathrm{CH}_{3}-\mathrm{C}_{6} \mathrm{H}_{4}-$ & 70 & $315-6$ & 1650 & 3330 & 1205 & 1690 \\
\hline
\end{tabular}

\section{FUNGICIDAL EVALUATION}

The colony diameter (mm) and \%Inhibition of Apergillus flavus on Sabauraud Agar Medium (SAM) treated with $2 \%$ compounds (2a-h) were shown in Table (2).

Table 2: Colony Diameter (mm) and \%Inhibition of Apergillus flavus On (SAM) medium treated with compounds(2a-h)

\begin{tabular}{|c|c|c|}
\hline $\begin{array}{c}\text { Compounds } \\
\text { No. }\end{array}$ & $\begin{array}{c}\% \\
\text { Inhibition }\end{array}$ & $\begin{array}{c}\text { Colony Diameter } \\
(\mathrm{mm})\end{array}$ \\
\hline $2 \mathrm{a}$ & 0 & 90 \\
\hline $2 \mathrm{~b}$ & 22.22 & 70 \\
\hline $2 \mathrm{c}$ & 22.22 & 70 \\
\hline $2 \mathrm{~d}$ & 17.11 & 74 \\
\hline $2 \mathrm{e}$ & 11.11 & 80 \\
\hline $2 \mathrm{f}$ & 10.0 & 81 \\
\hline $2 \mathrm{~g}$ & 16.66 & 75 \\
\hline $2 \mathrm{~h}$ & 11.11 & 80 \\
\hline
\end{tabular}

\section{REULTS AND DISCUSSON}

Scheme (1) summarizes the synthetic route followed for the preparation of the designed compounds. In this rout benzaldehyde and 2-amino-5-aryloxymethyl-1,3,4- 
thiadiazoles (1a-h) were reacted with barbituric acid under MW irradiation to give Mannich products $(2 \mathrm{a}-\mathrm{h})$. In this work, the organic compounds adsorbed on the surface of inorganic magnesium sulfate to support the absorption of microwaves irradiations. The bulk temperature was relatively low in such solvent free reactions although highly localized temperatures may be reached during microwave irradiation.

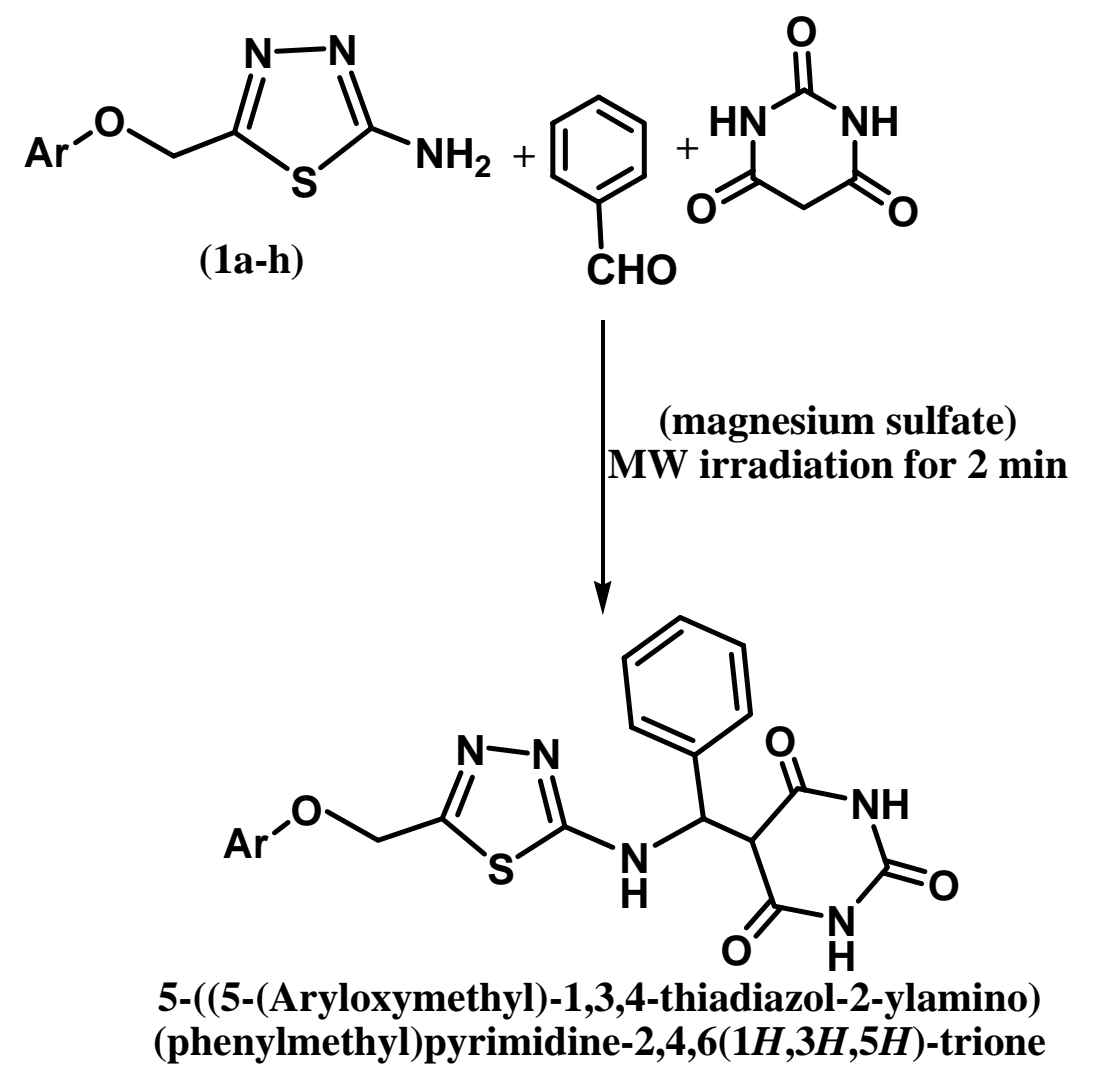

\section{Scheme (1)}

In conventional method the attempts to react amine (1a) with aldehyde to form Schiff base and the reaction of this base with barbituric acid did not succeed as was referred in literatures (Belinelo et al., 2002; kidawi et al., 2005).

All these bases were screened for their antifungal activity against Aspergillus flavus and found to possess bad activity. (Table 2).

\section{CONCLUSION}

The advantages of this work were the safe and simplicity with a good product yield, short reaction time and exclude the volatile and toxic solvents.

\section{REFERENCES}

AL-Gwady, Moayed, S.; Saied, S.M., and Mohamad, S.J., 2007. A Comparative Studies Between Microwave And Conventional Techniques Using Different Catalysts To Synthesis Of New Isobenzofurns, 10th scientific conference for foundation of technical education Baghdad. 
Ayoub, M.T.; Shandala, M.Y.; Saad E. Al-Mukhtar, and Noori, M.S., 2001. Brigehead nitrogen heterocyclic: Synthesis of Fused Heterocyclics from 3-substituted methyl-m1,3,4- triazole-5-thion (part iv); Raf. Jour., Sci, Vol. 12, No.4, pp.19-28.

Bahmanyar, S., and Houk, K.N., 2003. Origins of Opposite Absolute Stereoselectivities in Proline-Catalyzed Direct Mannich and Aldol Reaction. Organic Letters; vol. 5; no. 8, pp.1249-1251.

Barbas, C.F.; Wolfgang Notz; Fujie Tanaka; Shin-ichi Watanabe; Naidu S. Chowdari; James M. Turner, and Rajeswari Thayumanavan, 2003. The Direct Organocatalytic Asymmetric Mannich Reaction:Unmodified Aldehydes as Nucleophiles. JOC Article; J. Org. Chem., 68, pp.9624-9634.

Basher, A.A., 2005. Isolation and identification of some indoor dust fungi and their effect on the respiratory system. M.Sc. Thesis, College of Sciencs; Univ. of Mosul; Iraq.

Belinelo, V.J.; Reis, G.T.; Stefani, G.M., and Pilo-Veloso, D., 2002. Mannich base applied in this example: Synthesis of 6a, 7b-dihydroxyvouacapan-17b-oic acid derivatives. Part IV: mannich base derivatives and its activities on the electrically stimulated Guinea-pig ileum preparation. J. Braz. Chem. Soc. 13: pp.830-837.

Kidwai, M.; Ruby Thakur, and Richa Mohan, 2005. Ecofriendly Synthesis of Novel Antifungal (Thio) Barbituric Acid Derivatives. Acta Chim. Slov., 52, pp.88-92.

Pitt, J.I., and Hocking, A.D., 1997. Fungi and Food Spoilage. $2^{\text {nd }}$ Gaithersburg, Maryland: Chapman and Hall, 593p.

Ralhan, N.K., and Sachdev, H.S., 1960. Synthesis of Barbituric Acid Derivatives. J.Sci., Ind.Res., 19, pp.215-218.

Saied, S.M., 1983. Synthesis of some heterocyclic derv. Of anticipated insecticidal activity. Ms.C. Thesis, College of pharmacy, Univ. of Baghdad, Iraq.

Saied, S.M., 2007. Synthesis and hypoglycemic activity of N-new 5-(1,1-diphenyl-1hydroxymethyl)-substituted oxa/thiadiazoles sulfonamides. 10th scientific conference for foundation of technical education Baghdad.

Shandala, M.Y.; Ayoub, M.T., and Noori, M.S., 1998. Benzilic acid as Synthonin Synthesis of Some New Polyfunctional Subsistuted 1,3,4-Oxadiazole and 1,2,3triazozole (Part1). Raf. Jour., Sci, Vol. 2, No.2, pp.34-39.

Shandala, M.Y.; Ayoub, M.T., and Noori, M.S., 2001. Synthesis of some new substituted thiosemicarbazides and their corresponding 1,2,4-triazole, 1,3,4-thiadiazoles and 1,3,4-oxadiazole(part iii). Raf. Jour., Sci, Vol3, No.1, pp.3-9.

Shandala, M.Y.; Ayoub, M.T., and Noori, M.S., 2002. Synthesis of 5-substituted-1,3,4oxadiazoline-2-thiones and related compounds derived from diphenyl acetic acid (part ii). Raf. Jour., Sci, Vol. 13, No.1. 